\title{
CHARACTERISTICS OF HYPOSPADIAS PATIENTS IN PLASTIC RECONSTRUCTIVE AND AESTHETIC SURGERY DIVISION AT NATIONAL HOSPITAL CIPTO MANGUNKUSUMO JAKARTA
}

\author{
Indri Aulia ${ }^{1^{*}}$, Chaula L. Sukasah ${ }^{1}$, Evanti Kusumawardani ${ }^{2}$
}

\begin{abstract}
Background : Hypospadias is a genital congenital abnormality with a variable prevalence. There are risk factors associated with hypospadias. This study analyse the characteristics of hypospadias patients, hypospadias with other genital anomalies, and family history of hypospadias.

Method : We used the National Hospital Cipto Mangunkusumo Medical Record Database, which contains all the patient's data from 2013 to 2017. All the information of the diagnosis, type of hypospadias, and the family history are provided. After collecting all the data, we analysed the total cases of hypospadias and the characteristic of hypospadias patients.

Result : Based on the data, 6,254 patient that registered in the Plastic Surgery Division, forty-nine patients were diagnosed with hypospadias. Among them, $16 \%$ are penoscrotal type hypospadias. Furthermore, there is only $3 \%$ of the patients who has a history of hypospadias running in the family. Approximately $29.4 \%$ of the patients associated with other genital anomalies. However, only $35 \%$ of the sample population underwent surgical repair at the age of $0-5$ years.

Conclusion: The number of hypospadias cases treated by Plastic Surgery Division at The National Hospital Cipto Mangunkusumo is parallel with the global prevalence of hypospadias. The most common hypospadias type treated in Cipto Mangunkusumo Hospital is penoscrotal, which is similar to the previous study in Europe. The prevalence of hypospadias in Indonesia remains unknown therefore, the data management of hypospadias patients ought to be improved.
\end{abstract}

Keywords: Characteristic; Hypospadias; Genital Anomaly; Epidemiology

Latar Belakang: Hipospadia merupakan kelainan kongenital pada penis dengan prevalensi yang bervariatif. Terdapat faktor resiko yang mempengaruhi bayi lahir dengan hipospadia. Pada penelitian ini dilakukan analisis karakteristik pasien hipospadia, hipospadia dengan kelainan genitalia lainnya, dan riwayat keluarga dengan hipospadia.

Metodologi: Data yang digunakan merupakan data rekam medis RS Cipto Mangunkusumo tahun 2013 sampai 2017. Data yang diambil adalah diagnosis, tipe hipospadia, dan riwayat keluarga pasien. Setelah mengumpulkan data, dilakukan analisis total kasus dan karakteristik pasien hipospadia.

Hasil: Berdasarkan data, terdapat 6.254 pasien terdaftar sebagai pasien Divisi Bedah Plastik pada tahun 2013 sampai 2017. Empat puluh sembilan diantaranya merupakan pasien hipospadia. Terdapat $16 \%$ pasien terdiagnosa hipospadia penoskrotal dan hanya $3 \%$ pasien yang memiliki riwayat keluarga dengan hipospadia. Tiga puluh lima persen pasien mendapatkan tatalaksana pada usia 0-5 tahun.

Kesimpulan: Total kasus hipospadia yang ditangani di Divisi Bedah Plastik RS Cipto Mangungkusumo sebanding dengan prevalensi hipospadi dunia. Kasus hipospadia penoskrotal adalah kasus terbanyak ditangani sesuai dengan penelitian yang dilakukan di Eropa. Indonesia belum memiliki angka prevalensi untuk kasus hipospadia secara keseluruhan, sehingga pengembangan registrasi hipospadia dirasa perlu.

Keywords: Characteristic; Hypospadias; Genital Anomaly; Epidemiology 


\section{INTRODUCTION}

Hypospadias is a congenital anomaly of the penis, in which the urethral orifice is not located on the tip of the penis. ${ }^{1}$ Hypospadias classified into anterior, medial, and posterior. Anterior hypospadias is a condition where the urethral orifice lies at the glans of the penis, but not in the most distal part. Hypospadias media or middle hypospadias is a condition where the orifice located in the middle of shaft penis, while posterior hypospadias is where the orifice located at penoscrotal, scrotal, or perineum area. Physical examination of hypospadias not only determine the location but also chordee of the penis and the preputium condition. 1,2.

Hypospadias has commonly appeared as a single anomaly, however, it might be associated with another congenital anomaly.1 Several syndromes associated with hypospadias such as Smith-Lemli-Opitzz syndrome, WAGR syndrome, G syndrome, Wolf-Hirschhorn syndrome, and $13 q$ deletion syndrome. The existence of these syndromes usually appear with mental retardation, face dysmorphic, and anorectal malformation. Another condition frequently related to hypospadias patients is a Disorder of Sex Development (DSDs). This condition related to undescended tested, which needs to perform karyotyping test for further investigation. 1,2 .

The prevalence of hypospadias varies from 2 until 43.2 cases per 10.000 live birth. 3 The prevalence in male is 1 from 300 men have hypospadias. A study in Taiwan shows that the first diagnosis of hypospadias happened in the first 3 years of life. 4 The probability of hypospadias is 13 times higher among those who have a history of hypospadias in the first familial degree or the core family. The prevalence of hypospadias depends on the risk factor in the area of the country. 1,2.

Hypospadias affected by two main risk factor, genetics and environmental factors. There are several hypotheses explaining pollution affect the risk of hypospadias. Water pollution plays a role in making bioaccumulation of the contaminant in the tissue and affected the development of the genital. Resulted in congenital anomalies such as hypospadias, undescended testes, and low level of sperm count. 1
Process of male external genitalia development affected by the production of androgen hormone. Exposure of diethylbestrol (DES) can interrupt gene expression and alter the development of the penis. In the animal study, exposure of estrogen during pregnancy resulted in hypospadias due to the disruption of the activation of transcript factor 3 , which is regulated by estrogen. 1,2 .

Other external exposure such as medication, food consumption, cigarette smoking, and alcohol consumption can be considered as risk factors as well. Maternal age is considered as one of the risk factors even it still cannot be explained clearly. 2,5.

Surgery is a definitive treatment for hypospadias. The main goal of the surgery is to make the urethral orifice at the terminal of the glans penis and the penis alignment to be normal. As a result, the penis can be well function, especially for coitus. 5.

Methods used to repair hypospadias are various, depends on the operator preference. The optimal age for reconstruction is 6 months, before potty training. In severe cases, the reconstruction can be done in two stages with six months interval, therefore the final reconstruction can be done at age one until two years old. 5 .

Surgical techniques play a role in the successful outcome. Condition of the skin, corpus spongiosum, and urethra need to be evaluated to select suitable techniques. For the anterior hypospadias, techniques that usually used are Meatal Advancement Glansplasty (MAGPI), glans approximation procedure (GAP), Methieu procedur or "flip-flap", and Snodgrass modification. 5.

In the severe cases of hypospadias and posterior hypospadias, the main goal is to save the urethral plate where the innervation and main blood supply placed. The procedure is undermining the plate and the chordee is separate from the chordee. From this procedure, the penis is expected to be straight during erection. The other common method is using Bracka buccal 2 stage repair.

Disclosure: The authors have no financial interest to disclose. 
The first stage is straightening the penis and eliminate the abnormal urethra. The urethra displaced with the graft from the buccal mucosa. The second stage aims to rebuild the new urethra and cover with the subcutaneous tissue to build the new urethral orifice. 2, 5

The method used in the Plastic Reconstructive and Aesthetic Surgery Division at RSUPN Cito Mangunkusumo is Sidik Chaula Two-Stage Urethroplasty. This method can be performed for all types of hypospadias. In the first stage, the main goal is to release the chordee and make a new urethra using the intragranular tunnel from the preputium flap. Followed by making a new urethra from the surrounding cutaneous tissue at the second stage. This technique is adopted from Ulrich T. Hinderer's techniques which using fasciocutaneous flap from tunica dartos. 6 .

The most common complication from the reconstruction is fistula. The other complication that might happen post-surgical intervention is urethral stricture, meatus retrusive, residual curvature, and abnormal penis shape. Fistula can be treated during the healing process, or if the healing is already completed, fistulectomy can be perform.7

These complications can be minimized by doing a long term follow up to monitor the healing process of the surgery. Ideally, follow-up can be done 3 months after surgery, followed by evaluation at 1 or 2 years and 4 or 5 years after. 7 .

\section{METHOD}

\section{Patient Population}

The Plastic Reconstructive and Aesthetic Surgery Division at National Hospital Cipto Mangunkusumo database gives information on the diagnosis and treatment given to the patient. In this study, the data were extracted from the patient's medical record administered from January 2013 December 2017.

Patients' characteristics such as the type of hypospadias, chordee, preputium, and scrotal transposition were taken from the patient's surgery reports.

\section{Statistical Analysis}

This study will be analyzed as a descriptive study using the application SPSS v. 25.

\section{RESULT}

The Plastic Reconstructive and Aesthetic Surgery Division at National Hospital Cipto Mangunkusumo has 6,254 patients registered. Only $49(0.7 \%)$ patients were diagnosed hypospadias. Fourteen patients were excluded due to inadequate data or loss to follow up.

The age of the patients taken from the first time diagnosed hypospadias at The National Hospital Cipto Mangunkusumo. The most common age is at the group age of $0-5$ years $34.3 \% \quad(n=12)$. The second is at the group age 6-10 years $(31,4 \%, n=11)$. Although there still $2.9 \% \quad(n=1)$

Table 1. The Age of the first diagnosis

\begin{tabular}{cl}
\hline Age Group & No.Cases (\%) \\
\hline $0-5$ & $12(34.3 \%)$ \\
$6-10$ & $11(31.4 \%)$ \\
$11-15$ & $8(22.9 \%)$ \\
$16-20$ & $3(8.6 \%)$ \\
$\geq 21$ & $1(2.9 \%)$ \\
\hline
\end{tabular}

Among these hypospadias patients, there is only $8.8 \%(n=3)$ of the patients has the first-degree familial history and $91.2 \%$ of them did not have a family history with hypospadias.

Most of the patient had penoscrotal hypospadias $48.6 \%(n=17) ; 5.7 \% \quad(n=2)$ had glanular hypospadias; $8.6 \% \quad(n=3)$ had subcoronal hypospadias; $2.9 \%(\mathrm{n}=1)$ had distal penile hypospadias; $14.3 \% \quad(n=5)$ had midshaft hypospadias; $8.6 \% \quad(\mathrm{n}=3)$ had proximal penile hypospadias; $8.6 \%(\mathrm{n}=3)$ had scrotal hypospadias; and $2.9 \%(\mathrm{n}=1)$ had perineal hypospadias.

The condition of the chordee is important for hypospadias cases. There are only $5.7 \%(n=2)$ cases with severe chordee; $11.4 \%$ with moderate chordee; $2.9 \%(\mathrm{n}=1)$ with mild chordee, and $80 \% \quad\left(n=\_28\right)$ without chordee. There are $17.1 \%(n=6)$ cases with the condition of bifid scrotum; $82.9 \%(n=29)$ has a normal scrotum. 


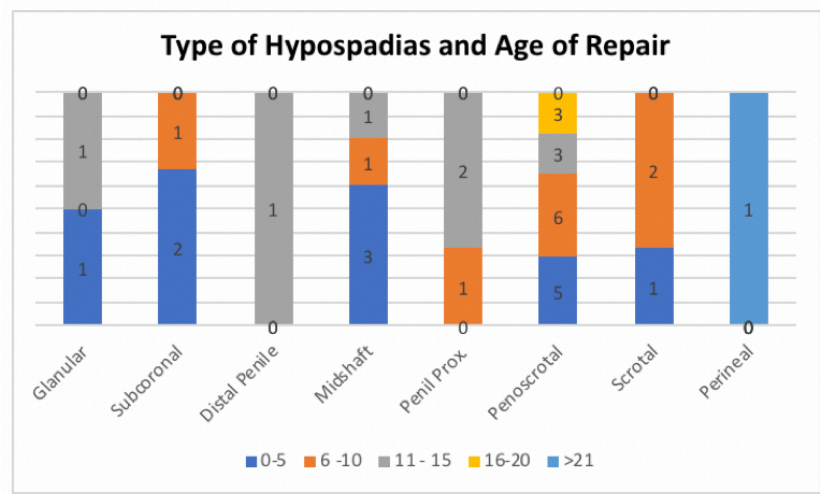

Figure 1. Type of Hypospadias and Age of the first

There are $28.6 \%(n=10)$ cases of hypospadias with another associated anomalies, while $71.4 \%(n=25)$ is an isolated hypospadias [Table 2].

Table 2. Other condition related to hypospadias

\begin{tabular}{lc}
\hline Other Diagnosis & No.Cases (\%) \\
\hline Micro Penis & $5(14.2)$ \\
Buried Penis & $1(2.8)$ \\
Cryptorchidism & $3(8.5)$ \\
Imperforate Anus & $1(2.8)$ \\
\hline
\end{tabular}

\section{DISCUSSION}

Hypospadias prevalence in the world is various. In Indonesia, there is a lack of concern for this condition. The data of anomalies has not reported completely, therefore the prevalence of hypospadias per birth cannot be determined.

Hypospadias classified based on their severity. It depends on the location of the urethral orifice, there is anterior, middle, and posterior hypospadias. In contrast with a study in Taiwan, our study showed that most of the hypospadias case is considered to be severe with the following proportion, penoscrotal hypospadias $48.6 \% \quad(n=17) ; 8.6 \% \quad(n=3)$ scrotal hypospadias; and $2.9 \%(\mathrm{n}=1)$ perineal hypospadias. This result is similar to the study reported in the 1980s.

Diagnosis can be made in the age group $0-5$ years $(34.4 \%)$. The most diagnosed case is the penoscrotal type, then the midshaft type. In this case, the condition of severe hypospadias is easy to make because, despite the abnormal appearance, Indonesia has a culture for circumcision.
The age of first surgery is taken from the first diagnosis, the patients usually refer to the National Hospital Cipto Mangunkusumo right after diagnosed from their hometown. Even though most of the cases got their first repair surgery at the age of $0-5$, some patients got their first surgery during or after puberty. It is due to the lack of the facilities and awareness of hypospadias.

In this study, isolated penile defect case is higher than cases with associated anomalies. Even though is not $90 \%$ of the cases, this is similar to a study by Calzolari et al in 1986. The most commonly associated anomalies with hypospadias patients are cryptorchidism, inguinal hernia, small for gestational age, and prematurity. Patients with cryptorchidism in this study are $8.5 \%$ and associated with micropenis is $14.2 \%$. Patients diagnosed with cryptorchidism and hypospadias are must be suspected into the Disorder of Sex Development and make an indication for karyotyping. Although there is no case with a hernia, there is a case associated with imperforate anus. This patient is can be suspected in to the 13q deletion syndrome and need further treatment and diagnosis.

\section{CONCLUSION}

This study showed that the majority of hypospadias patients administered in Cipto Mangunkusumo have penoscrotal type hypospadias which is in line with the previous worldwide study in the 1980s. It is important to draw a diagnosis of hypospadias as early as possible to determine the treatment options ahead. This study demonstrates no statistically trends of hypospadias due to the lack of a registry system in Indonesia. The data management needs to be improved in purpose to have comprehensive data especially in the congenital anomalies area like hypospadias.

\section{Corresponding author : \\ Indri Aulia}

Division of Plastic Reconstructive and Aesthetic Surgery, Department of Surgery

Cipto Mangunkusumo General National Hospital drindriaulia@gmail.com 


\section{REFERENCES}

1. Warren T. Snodgrass, Nicol C. Bush. Hypospadias. In: Alan J. Wein, Louis R. Kavoussim Alan W Partin, et al. (eds.) Campbell-Walsh Urology. 11th edition. USA: Elsevier, Inc; 2016. p. 3399-3429.

2. Ahmed T. Hadidi. Hypospadias Surgery. International Workshop on Hypospadias Surgery. Medical University Vienna; 2006.

3. J. E. H. Bergman, M.K. Bakker, M. Loane, et al. Epidemiology of Hypospadias in Europe: a registrybased study. World J Urol. 2015; 33, 2159-2167.

4. Wei-Yi Huang, Yu-Fen Chen, Ya-Jun Guo, et al. Epidemiology of Hypospadias and Treatment Trends in Taiwan: a Nationwide Study. The Journal of Urology. 2011; 186, 1449-1454.

5. Laurence S. Baskin, Michele B. Ebbers. Hypospadias: anatomy, etiology, and technique. Journal of Pediatric Surgery. 2006; 41, 463-472.

6. Chaula L. Sukasah, Laureen Supit. Sidik-Chaula Urethroplasty and the Manset Flap for Non-Glanular Hypospadias Repair. Jurnal Plastik Rekonstruksi. 2012; 1, 74-81.

7. Gianantonio Manzoni, Aivar Bracka, Enzo Palminteri, et al. Hypospadias Surgery: when, what and by whom? BJU International. 2004; 94, 1188-1195 